\section{Science lobby urges UK to divert funds from military fields}

Philip Ball, London

Public funding of science and technology in Britain is too focused on weaponsbased research. So claims "Soldiers in the Laboratory", a report released this week by Scientists for Global Responsibility (SGR), a lobby group backed by some of Britain's best-known researchers.

The report, written by Chris Langley, a neurobiologist with the Hertfordshirebased consultancy ScienceSources, asserts that up to half of British public spending on military research and development should be diverted to more socially useful activities. It recommends spheres such as land-mine detection, conflict resolution, and water management.

SGR, a group of 600 scientists whose supporters include physicist Stephen Hawking and astronomer royal Martin Rees, argues in its report that such a shift would benefit both national security and economic competitiveness. It says that security would be better served by addressing global poverty issues, and that some British engineering companies would be fitter if they had to compete in non-military markets.

According to Stuart Parkinson, an electronic engineer and the group's director, Britain spends $31 \%$ of its research and development budget on military work, a proportion that is exceeded only by the United States.

The report argues that "the military sector has a disproportionate effect on science, engineering and technology". Links between the military and the academic world are increasing, it says, citing the 2002 launch of the Defence Technology Centres collaborations between industry, government and universities who work on defence problems. Three such centres exist so far, involving 18 British universities. And British companies with major interests in military research, such as BAE Systems and Rolls-Royce, currently fund some academic posts.

In a statement, the UK Ministry of Defence said that its weapons research is geared towards making weapons more accurate and bringing fighting to a "swift conclusion", reducing civilian casualties.

Parkinson is not sure that the UK government will heed the report's advice. But he feels that the time is right to raise such issues. "Since the end of the cold war, discussion around military research and development has almost disappeared," he says. "We'd like to reopen that debate."

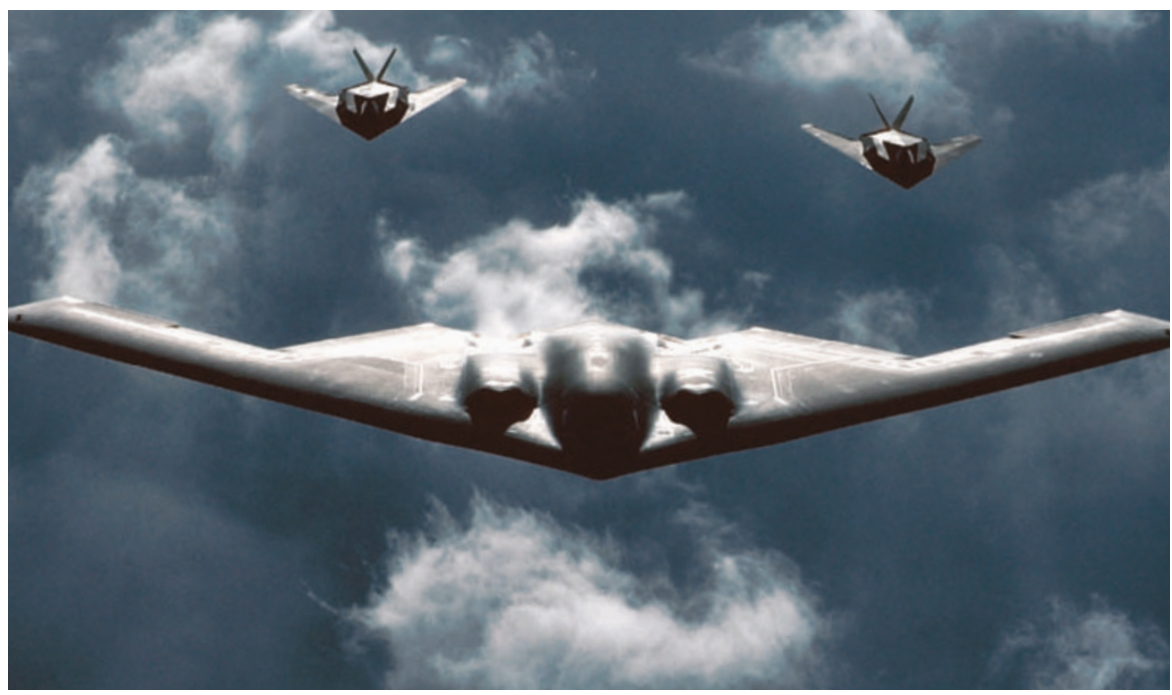

Bombs away? The United States continues to run a fleet of aeroplanes that can carry nuclear devices.

\title{
Antinuclear groups push to keep treaty review in the air
}

\section{Michael Hopkin, London}

The Nuclear Non-Proliferation Treaty (NPT) will become marginalized unless governments take a treaty review conference seriously, antiproliferation groups are warning.

An impasse exists, they say, between the United States, which critics regard as unenthusiastic about the treaty, and nations that have no nuclear weapons but want to see signs of disarmament from those that do. This threatens to let the treaty wither on the vine, the groups argue.

A report released on 11 January by the British American Security Information Council (BASIC) and the Oxford Research Group (ORG) says the New York conference, which is scheduled for 2-27 May, is crucial to the treaty's continued relevance. The two groups are planning a campaign in the runup to the meeting to make governments take the conference more seriously.

"We could break up on 27 May with the NPT in disarray," warns Ian Davis, director of BASIC. He says that "resentment and retrenchment" are brewing among the treaty's signatories as a result of differing interpretations of it and a widespread perception that it favours established nuclear powers. The treaty, which came into force in 1970 , calls on states with nuclear weapons to take concrete steps towards getting rid of them - but none has shown any sign of doing so.

The treaty's relevance is also threatened by the fact that India and Pakistan, which have each tested nuclear weapons, and Israel, which is widely assumed to possess them, have declined to sign it.

Proliferation experts continue, nonetheless, to view the treaty as important, because it is the main international agreement that seeks to restrain the proliferation of nuclear weapons.

The two groups plan to produce a series of non-technical research reports between now and May to detail the areas where progress might be made, says ORG director John Sloboda. They also aim to meet with key delegates, including Sérgio de Queiroz Duarte, the conference president and Brazil's ambassador-at-large for disarmament affairs.

Such efforts are welcome, says Trevor Findlay, director of the London-based organization VERTIC, which promotes effective verification of nations' compliance with agreements such as the NPT. However, he questions the claim by ORG and BASIC that the treaty is in danger of collapse. "I think it's a longer-term danger," he says. "Nuclearweapons states have tended to ignore their disarmament obligations. But the treaty is vital to them and they know it."

At the last NPT review conference, held in New York in 2000, nuclear states agreed on a 13-step programme to move towards global disarmament. But the United States, in particular, has reneged on parts of this deal, claims Matt Martin, a BASIC analyst based in Washington DC. He cites the Senate's failure to ratify the Comprehensive Test Ban Treaty, a move that is called for as one of the 13 steps.

Martin says he is encouraged by last November's decision by the US Congress to block funding for several new nuclear programmes, including one to develop 'bunkerbuster' bombs (see Nature 432, 542-543; 2004). But his group wants to see signs from the nuclear-weapons states that they are prepared to work towards disarmament. 